\title{
Construction of Green Supply Chain for Organic Products
}

\author{
Blanka Tundys ${ }^{1}$ \\ Department of Logistics, Faculty of Management and Economics of Services, \\ University of Szczecin, ul. Cukrowa 8, 71-004 Szczecin, Poland \\ E-mail: blanka.tundys@wzieu.pl (Corresponding Author) \\ Andrzej Rzeczycki \\ Department of Logistics, Faculty of Management and Economics of Services, \\ University of Szczecin, ul. Cukrowa 8, 71-004 Szczecin, Poland \\ E-mail: andrzej.rzeczycki@wzieu.pl
}

\begin{abstract}
The literature indicates that green supply chain is not only dedicated for organic products. Rather, the authors take a focus on the analysis of processes, organizational and law issues and the implementation of innovations that include, among others, the green aspects (manufacturing, production, transportation). Connection of green supply chain with organic products seems to be very important, among other reasons, because the development of the market for these products is dynamic. The interest of these products is growing worldwide. Production of organic products is legally regulated. The final result of this work will identify the basis for building a model of green supply chain for organic products (with emphasis on agricultural products), the identification of the factors forming the basis for the construction, relationships between stakeholders and indicate which of the factors determine the greening supply chain and whether they are necessary or sufficient factors for the role of ecological products of the market.
\end{abstract}

Keywords: supply chain for organic products, green supply chain, greening of logistics processes.

\section{INTRODUCTION}

Analyzing the scientific literature and business practices it should be indicated on the growing interest of green supply chain. This type of supply chain is considered from different points of view, forming its framework, considering the dependence and impact on various stakeholders as well as analyzing the costs. Connected of green supply chain with organic products seems to be very important, among other reasons, because the development of the market for these products is dynamic. A report: The world organic agriculture. Statistic \& Emerging Trends 2014 (2014) shows that at the end of the year 2012 organic agriculture is used in 166 countries, than 88 from this countries has organic regulations. Organic agricultural land it is 37,5 million hectares (share of total agricultural land $0,87 \%$ ). In 2012 was 1,9 million producers of organic products. The largest areas of organic agricultural land are: Oceania (12,2 million hectares, $32 \%$ of the world's organic agricultural land) and Europe (11,2 million hectares, 30\%). The countries with the most organic agricultural land are Australia (12 million hectares) and United States (2,2 million hectares). In the European Union 5,6 percent of the farmland is organic. However, begs the question, is the supply chain of these products also eco-friendly and green? If not, is there a need to adapt the green supply chain solutions? Should be constructed for the eco-friendly products separate green supply chains? And if these chains are existing, what for requirements must be fulfilled? The questions allowed the authors to put the following thesis: There is a need to adapt solutions and assumptions also framework of green supply chain for the supply chains of organic agricultural products. The verification of this thesis will be the basis of the theoretical part of the work. The authors take into account both law and organizational regulations. High impact on construction the framework will have ecological aspect of regional products, with particular emphasis on European Union and United States norms. To achieve the objective of the research, it will be conducted the structured review and study of literature, reports and documents (e.g. EU Commission, USDA). Then it will be presented the theoretical basis for the structure of the supply chain for organic products and verification of the thesis.

Changes in the global market for products and the growing interest of organic products also require matching appropriate design and structure of the supply chain for these products. In the context of this article, supply chains of two selected products from organic farming - food and cotton will be presented. The choice was made due to the character of the chains, specific construction and the ability to identify differences and similarities in the requirements and standards for the construction of this type of chain (Figure 1).

Referring to the previously presented thesis should be noted that: there is an explicit difference in the construction supply chain for conventional and organic products. Also supply chains for the organic products are differently constructed and dependent on the nature of the product. Considering two supply chain of organic farming (cotton and food products) it can be concluded that, although both can fulfill requirements for the greenness and environmental of chain, their structure is different. It should be also pointed out, that there is a need to create green supply chains for organic products, because only then all processes will meet environmental requirements.

\footnotetext{
${ }^{1}$ This paper is as part of project financed by National Science Centre granted on the basis of the decision DEC2013/09/B/HS4/02707
} 


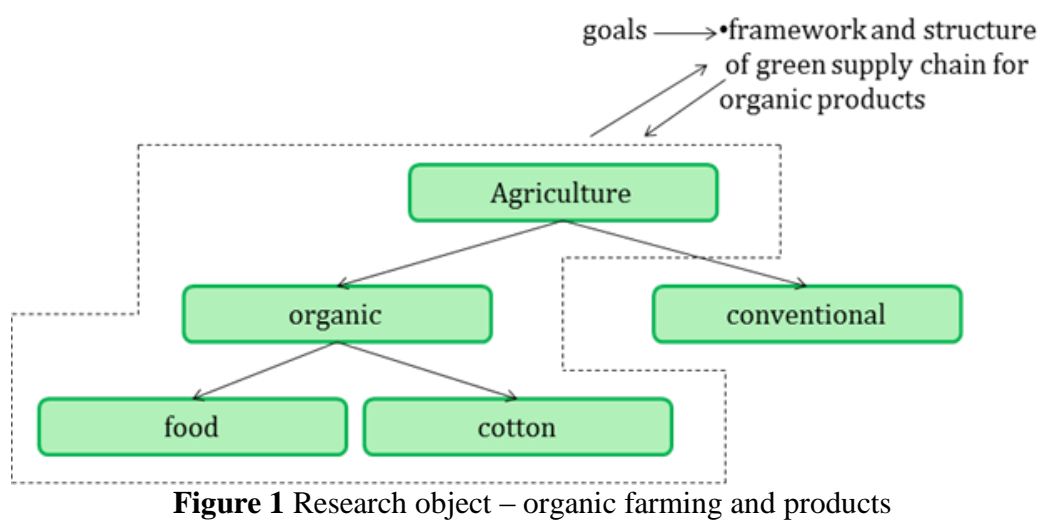

\section{METHODOLOGY}

The application process will be preceded by a phase of analysis and research. The main element will be the presentation of conditions and the relationship between the creation of eco-friendly products and supply chain. The authors try to indicate whether organic products to require green supply chain and a green supply chain part of the strategy for this type of product. The results will be the basis for both scientific discussion and practical verification of the model. It will provide a foundation for the start of the study and the confrontation of theory with business practice. The above considerations are parts of the first phase of research, which in the next stages of research will be extended by supply chain stakeholders, manufacturers of organic products, and consumers.

\section{LITERATURE REVIEW}

This paper builds on the primary literature, reports and survey of research organizations involved in organic production and in such products. It's following: (1) green supply chain theory, (2) the definition of organic products, farming, law regulation and certifications, (3) design for supply chain for organic cotton and organic food (4) correlation between construction of supply chain for organic product and (5) similarities and differences between supply chain for this products.

\subsection{Supply chain}

Supply chain is a network of interconnected businesses, whose goal is the realization of the needs and requirements of the clients reported in relation to particular goods or services. This type of chain consists of companies involved directly or indirectly in all phases of satisfying the needs of customers. That means, manufacturers, suppliers and distributors are not only included, as well as transport companies, warehouses, various types of intermediaries (retailers) and customers. In a related network of businesses engaged in the implementation of the client's needs transforming raw materials, semi-finished products into finished products delivered to the final customer. In the supply chain it is spoken about management, which will consist of the coordination of traditional business functions and strategies used in the organization and other entrepreneurs who are participants in the chain, which are designed to increase the efficiency of individual entities as well as the whole of chain. So it is a coordination of the production, storage, transportation, location in the supply chain, and its aim is to achieve the best possible combination and flexibility and efficiency of the market. Supply chain management includes not only all the tasks of logistics, but also marketing, new product development, finance and customer services. In the basic model of supply chain management it can be distinguished in five areas: production, inventory, location, transportation, information. However, each chain has its own unique set of market requirements and operational challenges. Companies need to make their own individual decisions and collectively consider their actions in the areas outlined above [Hugos 2006]. On the basis of the traditional approach and structure of the supply chain were established as green supply chain and green supply chain management.

\subsection{Green Supply Chain}

The essence of green supply chain is well known in the literature and in depth already described. For many years, the subject matter is described in the literature [Srivastava, Sarkis, Beamon]. Green Supply Chain Management (GSCM) is defined as 'integrating environmental thinking into supply-chain management, including product design, material sourcing and selection, manufacturing processes, delivery of the final product to the consumers as well as end-of-life management of the product after its useful life' [Srivastava 2007]. GSCM has emerged 'as an important new archetype for enterprises to achieve profit and market share objectives by lowering their environmental risks and impacts while raising their ecological efficiency' [Zhu et al., 2005], green supply management asserts that environmental collaboration was defined specifically to focus on interorganizational interactions between supply chain members including aspects such as joint environmental goal-setting, shared environmental planning, and working together to reduce pollution or other environment as impacts tried to minimize the unexpected environmental impacts of supply chain processes within the participating organizations and the whole supply chain [Vachon, Klassen 2008]. Pointing to the requirements for green supply chain it should be noted that it is expected by employees [Carter \& Jennings, 2004; Salam, 2009], expected by governments [Lee, 2008; Walker et al., 2008], an increasingly important issue for business [Sarkis, Zhu, \& Lai, 2011; Vachon \& Klassen, 2008, Capgemini Consulting's 2011]. Green supply chain should also benefit its participants, but also external stakeholders. The most important of them are: cost reduction [Carter \& 
Dresner, 2001; Zhu \& Sarkis, 2006], improved product and process quality [Lamming \& Hampson, 1996], risk reduction [Welford \& Frost, 2006], improved financial performance [Rao \& Holt, 2005], power advantage of the buyer [Carter \& Carter, 1998; Hall, 2000], create a multiplier effect [Preuss, 2001]. The construction of this type chains should be taken into account as lean supply chain management (Kleindorfer, Singhal, \& Wassenhove, 2005; Rothenberg, Pil, \& Maxwell, 2001; Simpson \& Power, 2005), reverse logistics and recycling (Guide \& Van Wassenhove, 2002; Wu \& Dunn, 1995].

\subsection{Green Supply Chain for Organic Products}

Analysis of literature covers issues related to the construction and management of green supply chain. The authors interest focused on examining whether organic products have also those supply chains. The starting point is a green product (according to the definitions and requirements outlined in the next section). The authors try to analyze the example of selected products, whether their supply chains are green.

Based on the definitions presented above it is indicated the supply chain, green supply chain management and what kind of benefits are expected from such structure of chain. In the context of the thesis, it should be given a thought and consideration to the design of supply chain for organic products. It is important that both in literature and in business practice are not dedicated to solutions for green supply chain only for organic or conventional products. This is actually a new philosophy of management and response to global economic trends. The construction of green supply chain has not actually anything to do with the products that it covers. So it is the organic products used in conventional supply chains or green supply chains? It seems logical that producers of organic products should also take into account the activity of the green supply chain. Research literature and analysis of case studies indicates that the specificity of organic products requires specific solutions in the supply chain.
Considering the supply chains it should pay attention to three elements: processes, products and procedures (documents). Green supply chain of organic products must meet the following requirements: green processes, transportation, warehousing, procurement, delivery, manufacturing, green procedure: electronic improved forecasting, POS sharing, electronic orders, electronic orders changes, electronic acknowledges, electronic invoices, carrier, and green (organic product) - the legal standards, and certification.

Authors are focused on the relationship of the various elements and the formation of the same chain. From the perspective of this article it will be important to connect two aspects and to examine the correlation between them, namely the green products and their supply chains. Theoretical construction of supply chain for organic products shows Figure 2.

Thus we do not construct and explore the chain itself and we do not point organizationally, strategically which items should be green, but we explore or we are given to say in organic products the chain is green. And in this context we are interested in what its structure is, how it looks and whether it is the same for different products. Presentation of two examples of products and their supply chains should point out the differences similarities, but also multifaceted construction of such chain.

\section{LEGAL AND ORGANIZATIONAL REQUIREMENTS FOR ORGANIC FARMING}

In this part it will be presented assumptions of organic farming, organic product and specifics depending on the type of product and the supply chain for the selected product._Considerations will be based on the legal and organizational requirements force in the United States and the European Union._Beginning with the indication of definition of organic food and cotton through the requirements of organic farming and the necessary certificates.

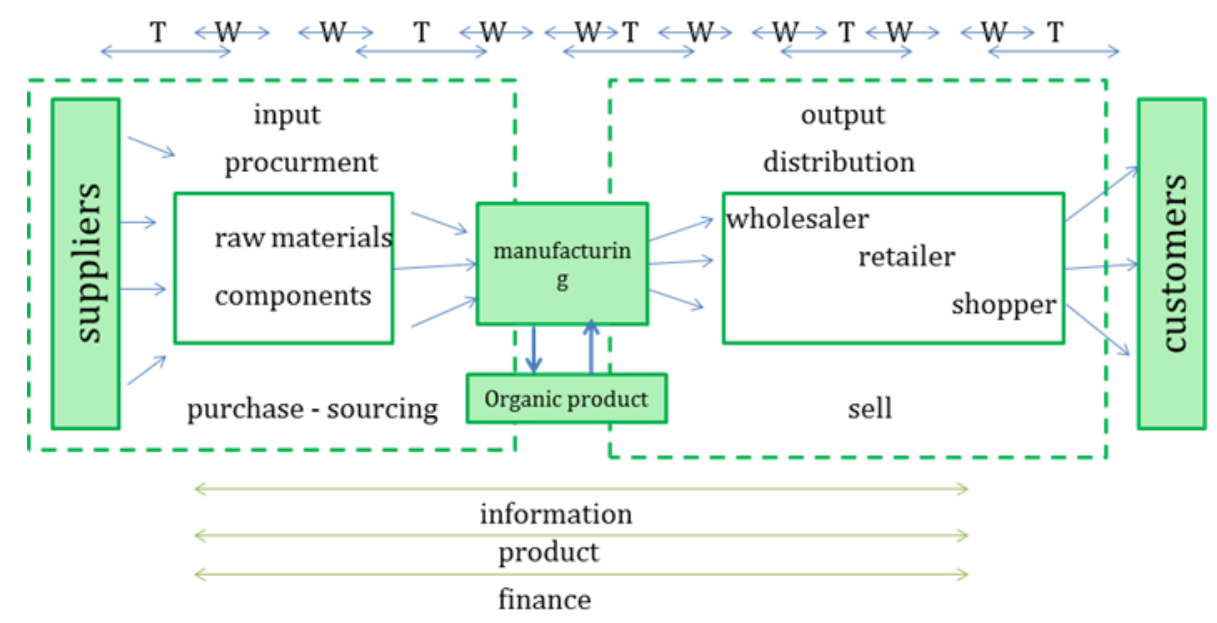

$\mathrm{T}$ transport

W warehousing

Figure 2 Theoretical construction of supply chain for organic products 


\subsection{Organic products}

Food and cotton they to be labeled "organic", both in the U.S. also in EU, must contain at least 95 percent organic ingredients. Besides food organic products are characterized by the fact that, they were supervised during the manufacturing processes and have been prepared in accordance with accepted guidelines. They are sold directly by the manufacturer or in a closed, secured and labeled package, to the product, which is located to the name of the manufacturer, processor and seller as well as the code and the name of the certification organization. Organic food is produced by farmers who emphasize the use of renewable resources and the conservation of soil and water to enhance environmental quality for future generations. Organic meat, poultry, eggs, and dairy products come from animals that are given less antibiotics or growth hormones as usual. Organic food is produced without using most conventional pesticides; fertilizers made with synthetic ingredients or sewage sludge; bioengineering; or ionizing radiation [USDA 2014]. Organic foods are produced using methods of organic farming.

Cotton is one of the most commonly cultivated plants in the world. Organic textile crops (mainly cotton) were grown 62,5 million hectares of land [Statistic report 2014], its more than $4 \%$ of the cultivated fields around the globe. About 80 countries produce cotton on a commercial scale. Organic cotton is cotton grown without the use of hazardous chemicals, chemical pesticides or fertilizers. Organic cotton is grown using methods and materials that have a low impact on the environment. Organic cotton is grown without the use of toxic and persistent pesticides and synthetic fertilizers [http://www.ota.com/organic/mt/organic_cotton.html], but they needs also just like the conventional cotton production very much water (mostly groundwater).

Organic products have strict production and labeling requirements. Unless noted below, organic products must meet the following requirements: produced without excluded methods (e.g. genetic engineering), ionizing radiation or sewage sludge and they must have authorized certifications.

\subsection{Organic farming}

The requirements of organic farming are defined both in the U.S. and the EU (Table 1). For this type of production chemical pesticides and fertilizers are not in use. To the acceptable fertilizer belong green manure, compost, manure and minerals available in nature. The organic farms use animal nutrition primarily from their own organic farm or they buy the organic feed with an acceptable admixture of conventional feed._Organic foods do not contain artificial colors, fragrances, flavors, preservatives. An important element is the control of organic production. When it comes to food - organic farms are subject to annual inspection, which relates to a method of manufacture and is governed by the relevant legal acts. Full range control on farms and in processing plants is done at least once a year and carries out the authorized certification bodies._Control subject has not only all the household objects: fields, meadows, pastures, paddocks, stable, equipment, warehouses, storehouses, etc., but also the documentation of production: accounting records, proof of purchase of inputs and raw materials, the book holding (or records) labels (and advertising material), the balance of the collection (and purchased raw materials) and the sale of organic products. On the basis of the control protocol, the certification body assesses whether the household (or processing plant) meets the criteria, and then issues a certificate of compliance authorizing the marketing of organic farming.

USDA (United States Department of Agriculture) and the National Organic Standards Board (NOSB) reported current definitions of organic farming (1995). The final national organic standards rule was published in the Federal Register on December 21, 2000. The law was activated April 21, 2001. (PART 205-NATIONAL ORGANIC PROGRAM, CFR Regulatory Text, 7 CFR Part 205. Legal text talking about production and organic products is Council Regulation (EC) No 834/2007 of 28 June 2007 on organic production and labeling of organic products and repealing Regulation (EEC) No 2092/91, in which the basic concepts are defined and requirements for organic production. However, it should be noted that the project was already Proposal for a Regulation of the European Parliament and of the Council COM (2014) 180 final. 2014/0100 (COD), changing the earlier regulation. Based on both documents it must be noted that organic production is based on the principles of respect of the environment, in accordance with the principles of sustainable development, minimizing the use of non-renewable resources. Organic production is a sustainable management system for agriculture.

Table 1 Requirements of organic farming

\begin{tabular}{|c|c|}
\hline \multicolumn{2}{|c|}{ Organic farming } \\
\hline USA (USDA) & UE (EC) \\
\hline $\begin{array}{l}\text { Organic agriculture is an ecological production management system that } \\
\text { promotes and enhances biodiversity, biological cycles and soil biological } \\
\text { activity. It is based on minimal use of off-farm inputs and on management } \\
\text { practices that restore, maintain and enhance ecological harmony. } \\
\text { Organic' is a labeling term that denotes products produced under the } \\
\text { authority of the Organic Foods Production Act. The principal guidelines for } \\
\text { organic production are to use materials and practices that enhance the } \\
\text { ecological balance of natural systems and that integrate the parts of the } \\
\text { farming system into an ecological whole. Organic agriculture practices } \\
\text { cannot ensure that products are completely free of residues; however, } \\
\text { methods are used to minimize pollution from air, soil and water. Organic } \\
\text { food handlers, processors and retailers adhere to standards that maintain } \\
\text { the integrity of organic agricultural products. The primary goal of organic }\end{array}$ & $\begin{array}{l}\text { Principles: respect for nature's systems and cycles and sustainment and } \\
\text { enhancement of the state of soil, water, air and biodiversity, of the health } \\
\text { of plants and animals and of the balance between them; contribution to a } \\
\text { high level of biodiversity; responsible use of energy and natural resources, } \\
\text { such as water, soil, organic matter and air; respect of high animal welfare } \\
\text { standards and, in particular, fulfillment of animals' species-specific } \\
\text { behavioral needs; appropriate design and management of biological } \\
\text { processes based on ecological systems using natural resources which are } \\
\text { internal to the system by methods that: (use living organisms and } \\
\text { mechanical production methods; practice land-related crop cultivation and } \\
\text { livestock production or practices aquaculture which complies with the } \\
\text { principle of sustainable exploitation of fisheries; exclude the use of GMOs }\end{array}$ \\
\hline
\end{tabular}


Table 1 Requirements of organic farming (con't)

agriculture is to optimize the health and productivity of interdependent communities of soil life, plants, animals and people. Organic production. A production system that is managed in accordance with the Act and regulations in this part to respond to site-specific conditions by integrating cultural, biological, and mechanical practices that foster cycling of resources, promote ecological balance, and conserve biodiversity. and products produced from or by GMOs with the exception of veterinary medicinal products; are based on the use of preventive measures, when appropriate); restriction of the use of external inputs. Where external inputs are required or the appropriate management practices and methods referred to in point (e) do not exist, these shall be limited to: inputs from organic production; natural or naturally-derived substances; low solubility mineral fertilizers; adaptation, where necessary, and within the framework of this Regulation, of the production process, taking account of the sanitary status, regional differences in ecological balance, climate and local conditions, stages of development and specific husbandry practices; limitation of the use of non-renewable resources and external inputs to a minimum; recycling of wastes and by-products of plant and animal origin as input in plant and livestock production;

Source: own elaboration on basis of EU Council and USDA documents

Electronic Code of Federal Regulations]. The National Organic Program Final Rule (NOP) was developed by the USDA to implement the Organic Foods Production Act of 1990 (OFPA). The NOP is based on recommendations of the National Organic Standards Board (NOSB), which was appointed by the Secretary of Agriculture to provide advice to implement OFPA and to review substances allowed in organic production and handling.

The Global Organic Textile Standard (GOTS) is recognized as the world's leading processing standard for textiles made from organic fiber. It defines high-level environmental criteria along the entire organic textiles supply chain and required compliance with social criteria as well. GOTS certified could get companies whose products contain a minimum of $70 \%$ organic fibers. All chemical inputs such as dyestuffs and auxiliaries they are used must meet certain environmental and toxicological criteria. Selection of accessories and tools is limited in accordance with environmental aspects. For each wet-processing units required and mandatory are suitable treatment plants. At the same time all of processes must by comply with the minimum social criteria [http://www.ota.com/organic/mt/organic_cotton.html].

\subsubsection{European Union}

According to the legal conditions [based on EU $834 / 2007,2010,2014]$, the product can be considered as coming from organic production, if you have been saved, all procedures and legal regulations, which are contained in the regulation. Names, their derivatives or diminutives, such as "bio" and "eco", alone or in combination, can be used throughout the Union, in any language. Where the organic logo of the European Union is applied must be indicated the place of productions also appear of raw materials of which the product has been breeding. It is in the same visual field as the logo and shall take one of the following forms, respectively: "EU Agriculture ', where agricultural raw material was produced in the Union; "non-EU Agriculture", in which agricultural raw material was produced in third countries; "EU / non-EU Agriculture", where part of the agricultural raw materials and is manufactured in the Union and part was farmed in a third country. The word 'Agriculture' may be replaced by 'Aquaculture' where appropriate. The indication 'EU' or 'non-EU' may be replaced or supplemented by the name of a country if all agricultural raw materials of which the product is composed have been farmed in that country. For the indication 'EU' or 'non-EU' small quantities by weight of ingredients may be disregarded provided that the total quantity of the fixed by law in National Organic Program Subpart are General requirements for certification [http //www ecfr gov 
disregarded ingredients does not exceed $5 \%$ of the total quantity by weight of agricultural raw materials. The indication 'EU' or 'non-EU' shall not appear in a color, size and style of lettering more prominent than the name of the food.

Production of organic food beyond the requirements for the same products also requires the suitable structure of the supply chain. It seems to be most reasonable, due to the nature of the products and their characteristics suggest the structure and requirements of short chain short food supply chain (Figure 1).

Short supply chain is characterized by the fact that both manufacturers and the end consumers have the same goals, the fulfillment of which is possible by creating new possibilities for what is to strengthen local food chains. In this case, the producers regain an active role in the food system that eliminates the number of links and links in the supply chain, and consequently the distance traveled by food (food miles). Such a situation may be beneficial for the functioning of the supply chain, in particular taking into account the cost of logistics chain. There are other relationships between transport costs; there is a greater impact on external costs. Such a system is independent of the long, already traditional supply chains. On demand nature of the link and the products themselves do not appear in the intermediate elements, such as wholesalers, resulting in better contact between producers and consumers. Production is on a smaller scale, but thanks to the entire chain it can be greener and more environmentally friendly, prices and costs more fair and understandable. With such solutions, the consumer can know the "real" cost of agriculture. In fact, the products need not be expensive, the costs of which are generated by the distributors do not exist, or they are borne by producers and consumers. A short supply chain is a vital element in building healthy local economies. This solution definitely should be noted as well as for organic products and although it is generally said that organic food products have the supply chain, this solution is very good from the point of view of the system, so not only the production but also the supply chain.

The ideal situation would be that in which the company engaged in the distribution and supply of products to the processing plant (from organic farms) uses the ecological transport (you can specify this element as a postulate in the creation of organic food supply chain for organic products). Nowhere indicates that the supply chain of organic products is also environmentally friendly, but examining the specificity of the products themselves and the markets in which it is sold can be concluded that in most cases it is SFSC. Under such arrangements it should be pointed out that we should promote pro-environmental attitudes also in the structure and functioning of the supply chain. This allows you to reduce logistical costs and environmental risks associated with logistics activities. It is a common specific characteristic of SFSCs that they are highly value-laden and meaningful for their participants. The direct relationship between the producer and the consumer involves construction of knowledge, value and meaning about the product and its provenance, production and consumption, the producer and the consumer themselves, rather than solely an exchange of a product (Ilbery \& Maye, 2005; Marsden et al, 2000). SFSC is often seen as restore the tradition and authenticity of food production, as well as the principles of fair and fair competition. Consumers of organic products are more aware of their choices. SFSC distribution model is often referred to as: "small scale", "short", "traditional", "local", "environmentally sustainable", “embedded", "fair", "transparency", "traceability", "corporate social responsibility", "local economy", "lower emissions", "ruralurban linkages", "self-esteem" "social acknowledgement", "prestige of food producers", "sustainability" [F.Galli, G. Brunori, eds, 2013]. It does not always have to be very short chains. Fair trade products also have such a relationship (see classification of SFSC).

In the SFSC should be the choice to establish a direct relationship with local farming, aimed at getting fresh and environmentally sustainable food. This geographical proximity however does not translate in rigid criteria with regard to the distance. There is also the desire to know better the reality behind that food, which is the farmers, the farms, the characteristics of the production processes and the related problems. SFSC could be sustainably and healthily. The products are fresh and do not remain stored: when they arrive at the delivery point they are collected by consumers.

\section{Short Supply Chain \\ for Food Organical Products}

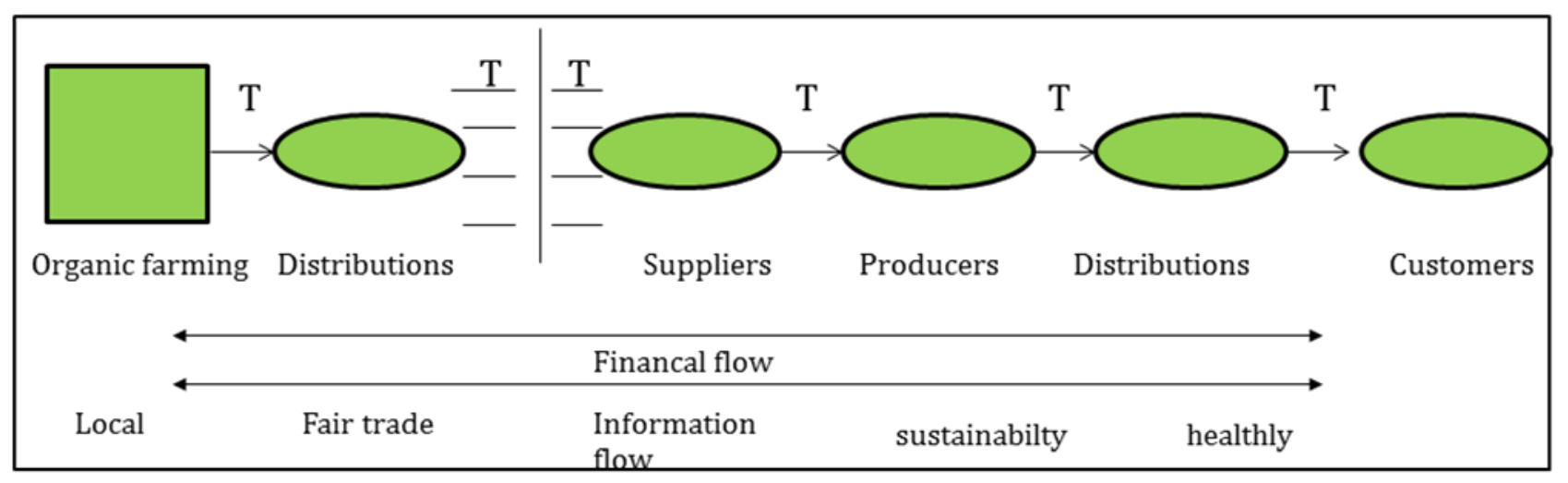

Figure 3 Design of SFSC

Source: own elaboration. 
Almost all the products are organic or biodynamic and the methods of processing are artisanal, without use of preservatives. Environmental sustainability: as said, the methods of production are organic or biodynamic and the farms are not far. The packaging is reduced as much as possible and recyclable or reusable materials are used for the packaging. Moreover, the producers make the deliveries on the same day, and this minimizes the transport impact. Social sustainability: the relationships established with the producers are based on mutual respect, solidarity, trust, and reciprocal knowledge. Economic sustainability: there are economic benefits for both parties. The producer can take advantage from a stable relationship, which raises the possibility to better organize the activity (the orders are generally for two or three months); moreover, the price is negotiated with the producers and the payments are in advance or at delivery. Consumers can benefit from good prices in relation to the quality of the products. [F.Galli, G. Brunori (eds.) 2013]. The study shows that not all organic products have this type of supply chains, especially taking into account aspects related to transport. In the part of the SFSC occurs redefinition of the relationship between the producer and the consumer, which show clear associations related to the origin of the food. The development of new relationships for new types of supply, demand new criteria that link price with quality criteria and the construction of quality. Usually, this food products are defined by the place and the farm where it has been produced and serves to enhance the image of the farm and the territory as a source of quality foods. Emphasis on the relationship between producer and consumer to construct value and meaning, rather than solely the type of product itself, and all these are summarized in the ability to engender some form of connection between the consumer and the food producer. [F.Galli, G. Brunori (eds.) 2013].

The two basic criteria needed to define SFSCs are physical and social proximity. As "short" indicates, in SFSC these distances are reduced in comparison to conventional food supply chains. Physical distance refers to the distance of transportation or food miles (Pretty et al, 2005; Hogan \& Thorpe, 2009) of a product from the place of production to the point of sale. Distance should be extended to the distance between the places of production of other inputs (e.g. pesticides, animal feed) Coley et al, (2011). Defining the SFSC it is said that a short food supply chain is created when producers and final consumers realize they share the same goals, which can be achieved by creating new opportunities that strengthen local food networks. It is an alternative strategy enabling producers to regain an active role in the food system, as it focuses on local production decentralized regional food systems that minimize the number of steps involved and the distance travelled by food (food miles) [http://www.earthmarkets.net/pagine/eng/pagina.lasso?-id_pg=2], the another definition: local food networks and short supply chains is not only focused on the distance between production and sale of the product, but also the number of links in the food supply chain, with the goal being to reduce these as much as possible - the shortest option being direct sales from the producer. In other words, short supply chain means reducing the number of intermediaries who are necessary to deliver the final product to the consumer." [R. Peters (ed.) (2012)].
Short food supply chains can be described as the range of food production-distribution consumption configurations - farmers' markets, farm shops, producers groups, etc. - which facilitate either a short distance and/or a small number of intermediaries between producers and consumers. The art of SFSC on the basis of the number of intermediaries, physical distance and organisational arrangements have identified as [own elaboration on basis: Renting et al. (2003) and F.Galli, G. Brunori, eds, 2013]:

1. Face-to-face SFSCs - there is the simplest and most direct type of chains where consumers purchase products directly from the producer or processor (on a face-toface basis). Authenticity and trust are mediated through personal interaction. The typical means through which these interactions take place include farmers' markets, roadside sales, on-farm sales, farm shops and 'pick-yourown'. In the case of the development of the e-commerce solutions such as: box schemes, mail order and the growing area of online sales offer possibilities to extend the geographical reach of these direct links.

2. Proximate SFSCs - in this case extend reach beyond direct interaction and are essentially delivering products, which are produced and retailed, within the specific region (or place) of production. For examples there would be local shops and butchers but also more specialized retailers such as whole-food shops, gourmet shops, etc. Another important set of intermediaries, which have importance meaning, are restaurants, hotels, and cafes etc. as they develop relationships with local producers. Another important type of proximate SFSC which is receiving increased attention is the small scale producers group or cooperative which allows farmers to brand their products collectively under a unique and authentic local brand. Consumers are made aware of the 'local' nature of the product at retail level (e.g. consumers' cooperatives, community supported agriculture).

3. Extended SFSCs - this category further enlarges the reach of SFSCs to extended relations in time and space. Products are sold to consumer outside the region of production who may have no personal experience of that locality. In most cases products are exported from the region to national markets, but some extended SFSCs may span large distances covering the globe. Examples of these are well-known regional specialties like Parma, Ham or Parmigiano Reggiano cheese but also 'fairtrade' products like coffee and tea. These kinds of networks are still 'short' food supply chains: It is not the distance over which a product is transported that is critical, but the fact that it is embedded with value-laden information when it reaches the consumer. The value and meaning laden information about the place of production and producers is transferred to consumers who are outside the region of production itself and who may have no personal experience of that region (e.g. certification labels, restaurants, public food procurement to catering services for institutions, printed on packaging or communicated of the point of retail). This enables the consumer to make connections with the place/space of production and with the values of the people involved and production methods employed. 
SFSCs represent an alternative type of governance and organization of food chains. Many of them are bottomup initiatives in which producers and consumers, who are often passive and subordinated participants in conventional global chains, become influential and active actors as owners of these chains who exert power and control in them. The role of territory evokes in local territorial resources and its contribution to territorial development. In such a case it could be made for the expansion of such initiatives. It seems to be reasonable that these elements were also regulated in the future organizationally and legally. Elements that affect the structure and appearance of the chain are shown in Figure 4.

\section{GREEN SUPPLY CHAIN MANAGEMENT FOR ORGANIC PRODUCTS - FRAMEWORK}

When considering issues related to the supply chain for organic products, it is decided to design and describe the chains for the two categories of products. In the first case it is spoken about a short supply chain for organic agricultural products, in the second of a global chain for organic products. Assumptions are actually similar, different is the design and other specifics regarding the sale of products. From the issues raised also shows that the structure should be adapted to the specificity of the products. Assumptions are actually similar, different is the design and other specifics regarding the sale of products. And so when we talk about organic agricultural products the analysis of case studies shows that by far they are a part of the implementation of short food supply chain (SSFCs). Despite indications over different types of this type of chain, it is said that the market is a strong local market, a short road transport as they are associated, among others, to be more traditional, locally embedded and sustainable farming practices (Ilbery and Maye, 2005; Goodman, 2003). Chains of this type focus on good contact supplier and recipient. These chains are characterized by the very small number (or even the absence of) intermediaries between producers and consumers, and/or by the short geographical distance between the two (they ideally fulfil both conditions) (Parker 2005).

How should and can be constructed green supply chains for organic products? Using the already known methods and practical experience for example; short food supply chains, while introducing them to the principles of green supply chain. This means that the chains must incorporate green processes. Whether it is a short or long chain, aware of the fact that a product is organic also requires the organization of the chain. In fact, without this same organic product becomes less important (at least for the more conscious customers).

The ideal situation would be one in which all processes will be green. This means that in addition to organic production, transportation will be eco-friendly (means of transport, optimal routing, properly loaded vehicle, no empty runs), distribution systems constructed in the most optimal, as the least expensive, thereby reducing the environmental costs of packaging - also organic or recyclable. It should be mentioned that the green chains should be a part of close loop supply chain. Ecological, feedback or biodegradable packaging and adequate packaging rebounds. When GSSFC may also be giving up a part of the package (products are sold without packaging at once to the final customer (fruits, vegetables, not processed). If storage also using green technologies or "magazine on the way" to reduce the costs, not only of the chain but also of the environment. Model-based green supply chain for organic products (short chain) presents a Figure 5.

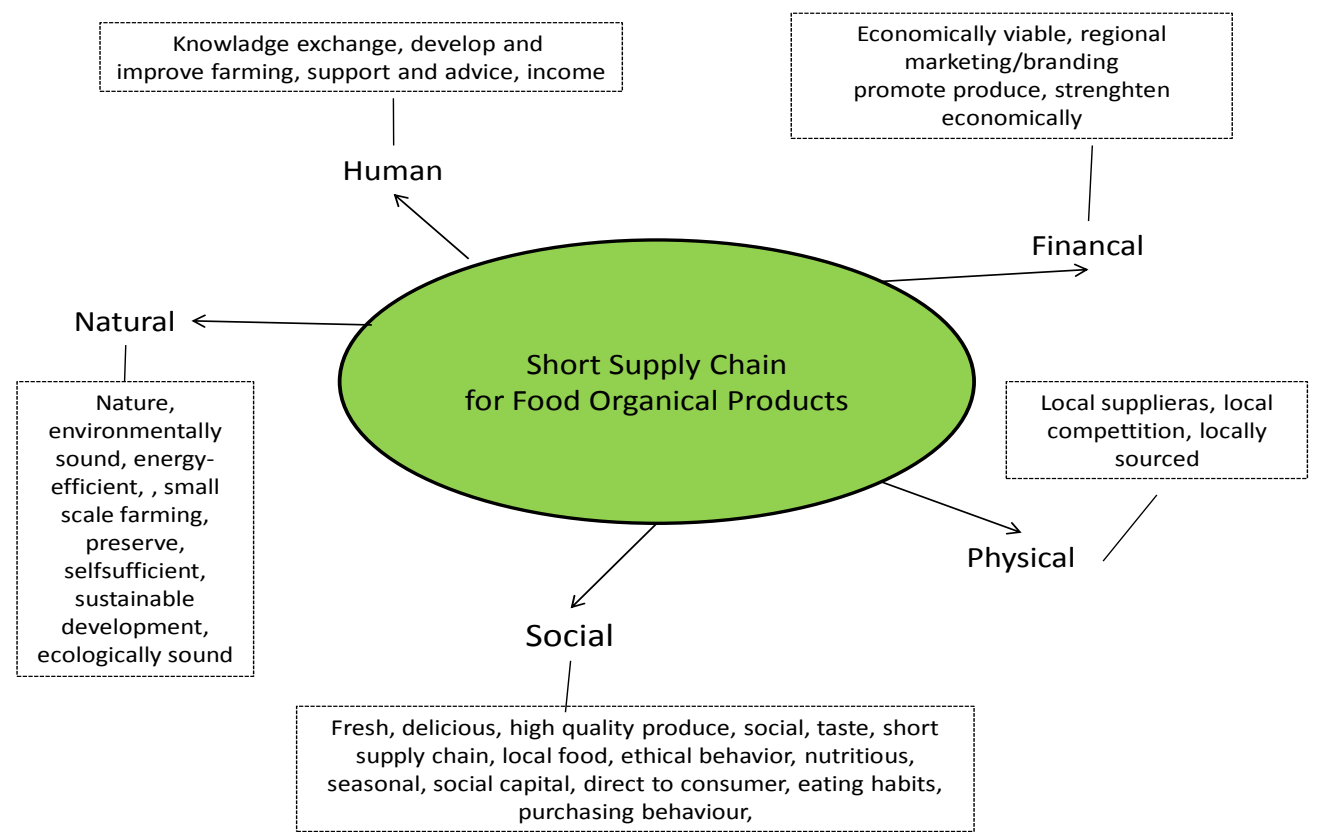

Figure 4 Areas of SSC for Organic Product Source: own elaboration 


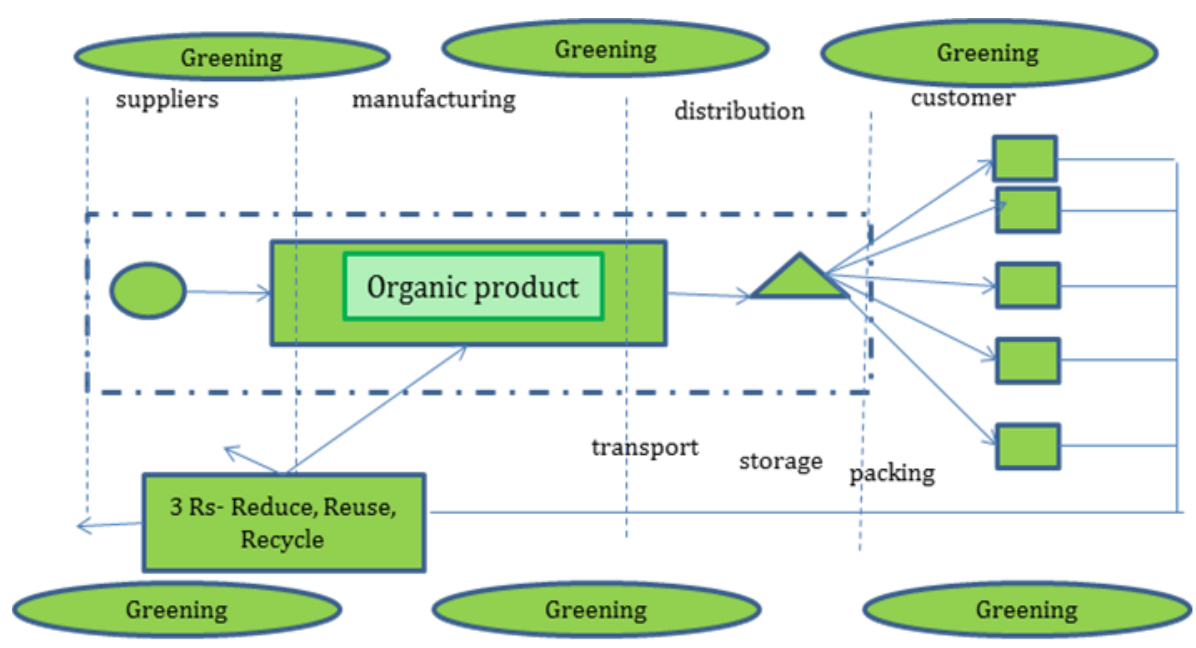

local markt - short supply chain

Figure 5 Green Supply Short Chain Source: own elaboration

In this case, the proper management of the process is not difficult. Appropriate coordination could foster the creation of such solutions and this supply chain. The situation becomes more difficult when we talk about the global supply chain. Good examples of greening the supply chain of organic cotton used mentioned previously, can be used examples of a global company C \& A. These are practical recognition of global supply chains that carry out processes taking into account environmental aspects. C \& A use to manufacture its products organic cotton, also seeks to transport goods in a manner least damaging to the environment. This is the beginning of the road to create a global green supply chains for organic products. Manufacture of textiles and trade has long been the global market, and the global supply chain. One of the consequences is a long supply chain and long routes. To create new business solutions, including green supply chain entrepreneur (parent company) forge business contracts with companies which provide a quality transportation, or undertaken to determine the clear rules for the protection of the environment and reduce harmful substances into the environment. Referred to the relevant requirements are that each link in the supply chain must fulfill. It is also important that other processes are efficiently and optimally organized. When the chain of textile products associated with most of the production takes place in the Far East, and the markets are Europe and the USA. Which means that is largely used intermodal transport and the transport of containers must be as efficient as possible. This means the full load of containers to a particular country and the port of destination, and then the use of rail transport continues. With such a product and the supply chain cannot be avoided transport.

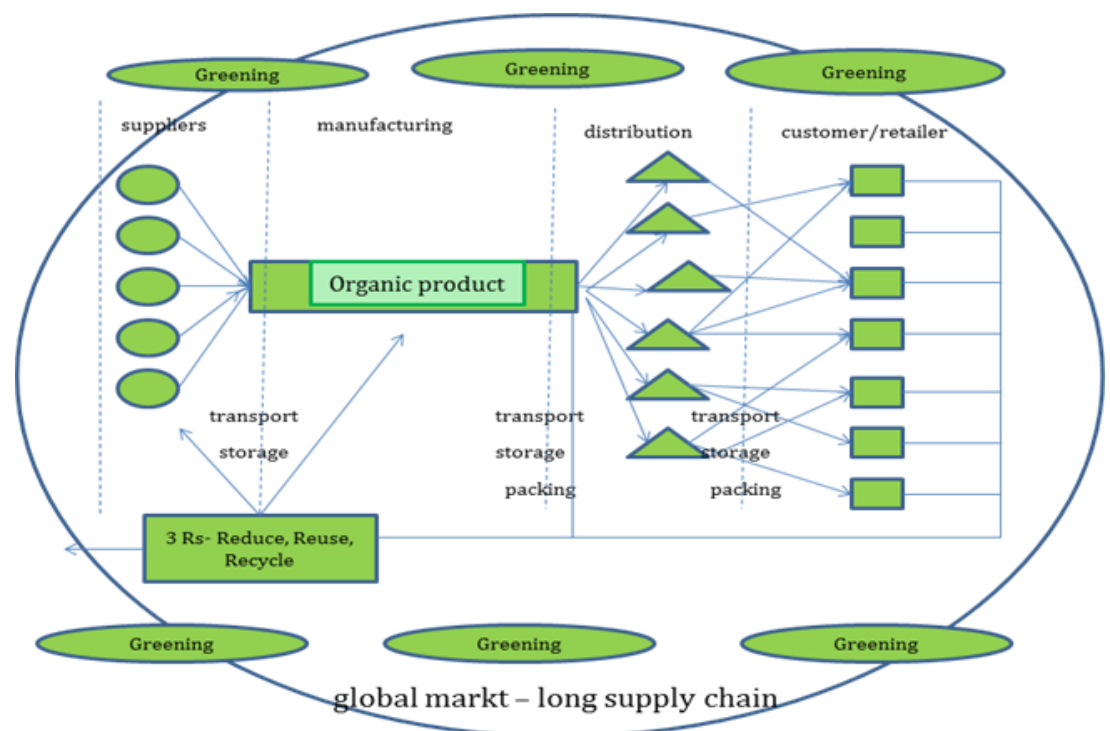

Figure 6 Green Supply Chain for Organic Products - Long Chain Source: own elaboration 
Important for the greening of the chain is the use of the latest technologies to optimize routes to minimize driving appropriate consumption and emissions, the use of appropriate vehicles (Euro 5 - European Emission Standard or biodiesel, but the use of Biodiesel is very questionable because the fuel production, made of rape - Rapeseed oil Methyl Ester RME generate more emission in production, there is more intensive landscape using, monocultures and is in conflict with food production). Another important element is the packaging - it should be used as reusable, recycled and suitable for reuse. With so understood the chain is also important customer awareness. Waste products should be placed in the collections that they can convert, process or re-use. Companies produce denim clothes off recycled fiber (from used products), then it will be processed and re-use. Model-based green supply chain for organic products (long chain) is shown in Figure 6.

\section{CONCLUSION}

Most of organic products in supply chains particularly made for food are involved in local producers and they working together to promote the local food markets. These partnerships help boost the rural economy, creating new ways of selling local produce and attracting new types of customer. They also promote cooperation between local farms, the tourist industry and the food sector. This situation could be supports sustainable development by reducing transport costs, $\mathrm{CO}_{2}$ emissions, and wear and tear on rural roads, traffic congestion, and road accidents. Organic farming is becoming more popular in the world; therefore the natural environment must reconstruct supply chains. It is a part of their business outside. The economic costs created social and ecological minimization and will contribute more complete, systematic approach to the problem, not just organic production, but also and above all the supply chain. Organic cotton now represents 0.76 percent of the global cotton production, and with green supply chain it could develop the market and encourage customers to buy such goods. Green supply chain is a part of supporting of organic products. In a holistic approach it should be considered holistically processes, and therefore it is considered that organic products require the construction of green supply chain. The end about the idea of GSC means to come near to the question about our way (people) in which we are living. It is necessary to save monetary cost in production (reduction of cost) when the price for saving costs will be paid by future generation. The costumer is the biggest uncertainty. He stands in the end of GSC and makes his decision not yet with respect to the objects of sustainable development, ecological farming or GSC. Mostly they want to have an inexpensive product. And for this, the SC will always be imperfect. But GSC could be the beginning of a new challenge in more than transport. All parts of chain (include and especially customers) should be connected with organic thinking and have one aim - to be green.

\section{REFERENCES}

Beamon B. (2008), Sustainability and the Future of Supply Chain Management. Operations and Supply Chain Management 1(1), pp. 4-18.
Carter, C.R., Carter, J.C. (1998), Interorganizational determinants of environmental purchasing: Initial evidence from the consumer products industries. Decision Science 29(3), pp. 659-684.

Coley, D., Howard, M., and Winter, M. (2011) Food Miles: Time for a Re-Think? British Food Journal 113 (7), pp. 919-934.

Coley, D., Howard, M., Winter, M. (2011), Local food, food miles and carbon emissions: A comparison of farm shop and mass distribution approaches. Food Policy 34(2), pp. 150155.

Council Regulation (EEC) $\mathrm{N}^{\circ} 834 / 2007$ of 28 June 2007 on organic production and labelling of organic products and repealing Regulation (EEC) No 2092/91

Davies J, Hochman S. (2007), The greening of the supply chain. Supply Chain Management Review 11(5), pp. 13-14

Eltayeb T. K., Zailani S. (2009), Going Green Through Green Supply Chain Initiatives Towards Environmental Sustainability, Operations and Supply Chain Management 2(2), pp. 93-110

Galli F., Brunori G.(eds.) (2013), Short Food Supply Chains as drivers of sustainable development. Evidence Document. Document developed in the framework of the FP7 project FOODLINKS (GA No. 265287). Laboratorio di studi rurali Sismondi, ISBN 978-88-90896-01-9

Gold, M. (2014), "What is organic production?". National Agricultural Library. USDA. Retrieved 1 March 2014.

Goodman, D. 2003. The quality 'turn' and alternative food practices: Reflections and agenda. Journal of Rural Studies 19(1), pp. 1-7.

Guide V.D.R. Jr., Van Wassenhove L.N. (Eds.) (2004). California Management Review 46 (2), feature issue on closed-loop supply chains.

Hall, J. (2000). Environmental supply chain dynamics. Journal of Cleaner Production 8(6), pp. 455-471.

Hogan, L. and Thorpe, S. (2009). Issues in food miles and carbon labelling, ABARE research report 09.18, Canberra, December,

http://www.earthmarkets.net/pagine/eng/pagina.lasso?-id_pg=2 http://www.ecfr.gov,

http://www.ota.com/organic/mt/organic_cotton.html

http://www.ota.com/organic/mt/organic_cotton.html

Hugos M. (2006), Essentials of Supply Chain Management, 2nd Edition,

Ilbery B, Maye D, (2005), Supply chains and sustainability: evidence from specialist food producers in the Scottish/English borders. Land Use Policy 22(4), pp. 331344

Ilbery, B., Maye, D. (2005) Alternative (shorter) food supply chains and specialist livestock products in the Scottish and English border. Environment and Planning A 37(5), pp. 823-844.

Kleindorfer P.R., Singhal K., van Wassenhove L.N (2005), Sustainable operations management. Productions and Operations Management 14(4), pp. 482-492.

Krejci, C. C., Beamon B., (2010). Environmentally-Conscious Supply Chain Design in Support of Food Security, Operations and Supply Chain Management 3(1), pp. 14-29

Lamming, R. C., Hampson, J. (1996), The Environment as a Supply Chain Management Issue, British Journal of Management, 7, pp. 45-62.

Lee, S.Y. (2008), Drivers for participation of small and mediumsized suppliers in green supply initiatives. Supply Chain Management: An International Journal 13(3), pp. 185-198.

Marsden T., Banks J., Bristow G. (2000) Food Supply Chain Approaches: Exploring their Role in Rural Development. Sociologia Ruralis 40(4), pp. 424-438.

Marsden, T., Flynn, A., Harrison, M. (2000), Consuming Interests: The Social Provision of Foods. London:UcL Press.

Moroney A., O'Shaughnessy M., O'Reilly S (eds.) (2013), Facilitating and Encouraging Short Food Supply Chains, A 
national rural Network report, June 2013, Department of Food Business and Development, UCC,

Pretty, J. N., A. S. Ball, T. Lang, and J. I. L. Morison (2005). Farm costs and food miles: an assessment of the full cost of the UK weekly food basket. Food Policy 30(6), pp. 1-19

Preuss L., 2001, In dirty chains? Purchasing and greener manufacturing. Journal of Business Ethics 34(3), pp. 345359.

R. Peters (ed.) (2012) Local Food and Short Supply Chains, EU Rural Review N 12 .

Rao P., Holt, D. (2005), Do green supply chains lead to competitiveness and economic performance? International Journal of Operations and Productions Management 25 (9), pp. 898-919

Renting, H., Marsden, T. and Banks, J. (2003) Understanding alternative food networks: exploring the role of short supply chains in rural development, Environment and Planning A 35(3), pp. 393-411.

Rothenberg, S., Pil, F., Maxwell, J. (2001). Lean, green and the quest for superior environmental performance. Production and Operations Management 10(3), pp. 228-243

Simpson, D. F., Power, D. J. (2005), Use the supply relationship to develop lean and green suppliers. Supply Chain Management: An International Journal 10(1), pp.60-68.

Srivastava S. K. (2007), Green supply-chain management: A stateof - the-art - literature review. International Journal of Management Reviews 9(1), pp. 53-80

The world organic agriculture. Statistic \& Emerging Trends 2014 (2014)

USDA United States Department of Agriculture, Report 2014. www.usda.gov
Vachon S, Klassen RD. (2006), Extending green practices across the supply chain: the impact of upstream and downstream integration. International Journal of Operations \& Production Management 26(7), pp.795 - 821

Walker H., Di Sisto L., McBain D, 2008, Drivers of environmental supply chain practices: lessons from the public and private sec tors. Journal of Purchasing and Supply Management 14(1), pp. 69-85

Welford,R.m Frost,S. (2006),Corporatesocial responsibility in Asian supply chains, Corporate Social Responsibility and Environmental Management 13(3), pp. 166-76

Willer H., Lernoud H. (Eds.) (2014), The World of Organic Agriculture. Statistic and Emerging Trends 2014. FiBLIFOAM Research Institute of Organic Agriculture (FiBL), Frick, and International Federation of Organic Agriculture Movements (IFOAM), Bonn. Revised version of February 24, 2014

Wu, H. J., \& Dunn, S. C. (1995). Environmentally responsible logistics system. International Journal of Physical Distribution \& Logistics Management 25(2), pp. 20-39.

www.abare.gov.au/publications_html/crops/crops_09/foodmiles_pr ecis.pdf>.

Zhu Q., Sarkis J. (2004) Relationships between operational practices and performance among early adopters of green supply chain management practices in Chinese manufacturing enterprises. Journal of Operations Management 22(3), pp. 265-289

Zhu, Q. H., Sarkis, J. (2006), An inter-sectoral comparison of green supply chain management in China: Drivers and practices. Journal of Cleaner Production 14(5), pp. 472486.

Blanka Tundys is an Assistant Professor at the Department of Logistics, at the Faculty of Management and Economics of Services, University of Szczecin, Poland. Her main research areas are: green supply chain management, green logistics, measurement of green supply chain, processes modeling and city logistics. She is an author and co-author of 70 publications and has written one book (City Logistics - in polish language, 2008 I. ed., 2013 II ed.). She was main contractor in 5 international research projects (finance by German Academic Exchange Services and Deutsch-Polnische Wissenschaftsstiftung). She has gotten three times a scholarship of DAAD (German Academic Exchange Services) foundation (2001, 2004-2005, 2011). In 2004-2005 she has gotten a scholarship at the Fachhochschule Osnabrück (Germany), while she was preparing her doctoral dissertation. She has gotten twice scholarship by LLP - Erasmus-Program.

Andrzej Rzeczycki is a Teaching Assistant at the Department of Logistics at Faculty of Management and Economics of Services, University of Szczecin, Poland. He has a wide range of research interests including the logistics strategy in supply chains, logistics systems and processes modeling, game theory in logistics, risk management. 